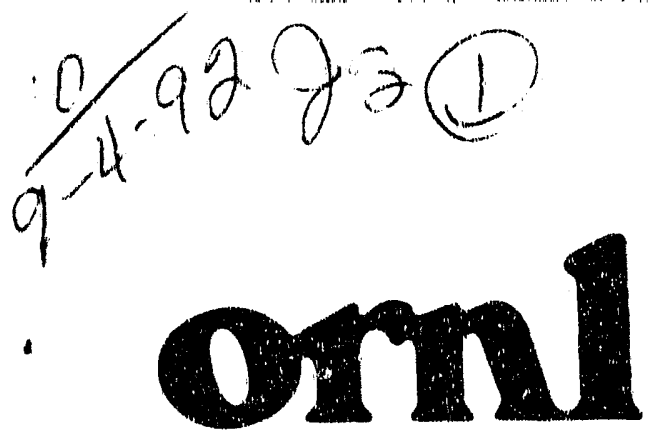

\section{OAK RIDGE NATIONAL LABORATORY}

makrow makperta
Protocol for Determination of Chemical Warfare Agent Simulant Meivement Through Porous Media

\author{
R. A. Jenhins \\ M. V. Buchaman \\ R. Mermweathe: \\ R. H. Hgner \\ T. M. Ciale \\ J. H. Moneyhum \\ A. P. Walson
}


This report has been reproduced directly from the best available copy.

Available to UOE and DOE contractors from the Otfice of Scientific and Techni. Cal information, PO. Box 62, Oak Ridge, TN 37831, prices available from (675) 576-8401, FrS 626.8401.

Available to the public from the National Technical Information Service, U.S. Department of Commerce, 5285 Port Royal Rd., Springfield, VA 22161.

This report was prepared as an account of work sponsored by an agency of the United States Government. Neither the United States Government nor any agency thereot, nor any of their employees, makes any warranty, express or implied, or assurnes any legal liability or responsibility for the accuracy, compheteness, or usetulness of any information, apparatus, product, or process disclosed, or tepresents thas its use would not intringe privately cowned rights. Reference herein to any specific commercial product, process, or service by trade narne, trademark manufacturer, or otherwise, does not necessarily constitute or imply its endorsement, recornmendation, or favoring by the United States Government or any agency thereot. The views and opinions of authors expressed herein do not necessarily gtate or reflect those of the United States Government or any agency thereof 
Analytical Chemistry Division

\section{PROTOCOL FOR DETERMINATION OF CHEMICAL WARFARE AGENT SIMULANT MOVEMENT THROUGH POROUS MEDIA}
R. A. Jenkins
M. V. Buchanan
R. Merriweather
R. H. Ilgner
T. M. Gayle
J. H. Moneyhun
A. P. Watson

Date Published - July 1992

Prepared for the

U.S. Department of the Army

Office of the Assistant Secretary

(Installations, Logistics and Environment)

under Interagency Agreement No, 1769-1354-A1

Prepared by the

OAK RIDGE NATIONAL LABORATORY

Oak Ridge, Tennessee 37831

managed By

MARTIN MARIETTA ENERGY SYSTEMS, INC.

for the

U.S. DEPARTMENT OF ENERGY

under contract DE-AC05-84OR21400 
LIST OF FIGURES $\ldots \ldots \ldots \ldots \ldots \ldots \ldots \ldots \ldots \ldots \ldots \ldots \ldots \ldots \ldots \ldots$

LIST OF TABIES $\ldots \ldots \ldots \ldots \ldots \ldots \ldots \ldots \ldots \ldots \ldots \ldots \ldots \ldots \ldots \ldots \ldots$

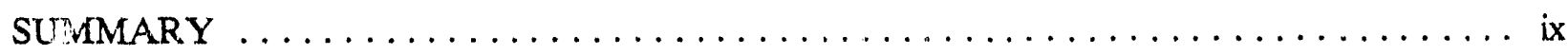

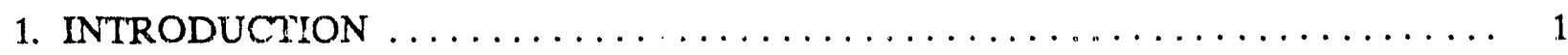

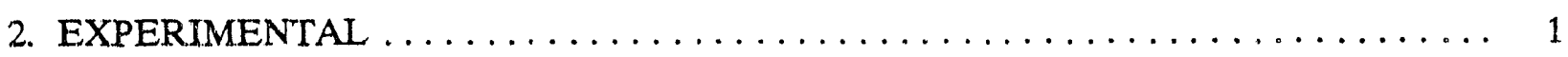

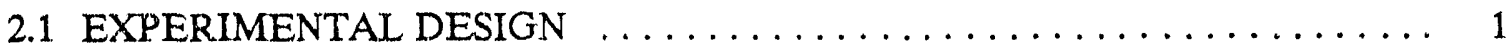

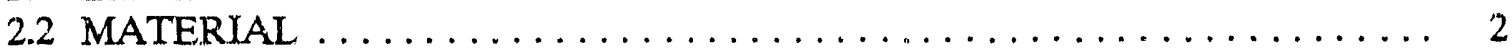

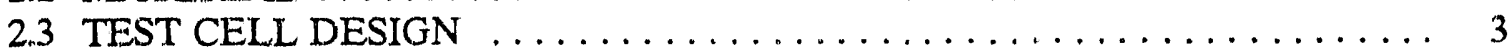

2.4 AIR SAMPLING AND FLOW DETERMINATION $\ldots \ldots \ldots \ldots \ldots \ldots \ldots 7$

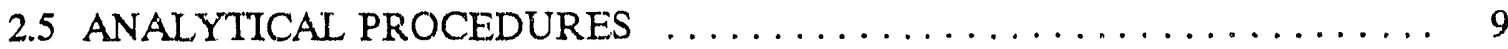

2.5.1 DIMP (GB simulant) and DMMP (VX simulant) $\ldots \ldots \ldots \ldots \ldots, 9$

2.6 PROCEDURES FOR DECONTAMINATION SIMULATION $\ldots \ldots \ldots \ldots \ldots .9$

2.7 RECOVERY OF AGENT SIMULANTS FROM TEST COUPONS $\ldots \ldots \ldots \quad 12$

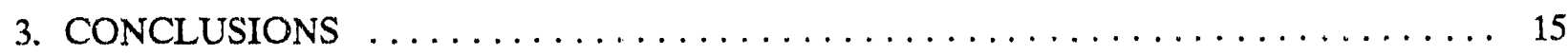

4. RECOMMENDATIONS FOR FURTHER WORK $\ldots \ldots \ldots \ldots \ldots \ldots \ldots \ldots$

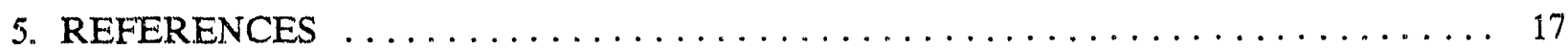




\section{LIST OF FIGURES}

Figure

Page

2.1. Schematic diagram of test cell $\ldots \ldots \ldots \ldots \ldots \ldots \ldots \ldots \ldots \ldots \ldots \ldots \ldots \ldots$

2.2. Disassembled test cell $\ldots \ldots \ldots \ldots \ldots \ldots \ldots \ldots \ldots \ldots \ldots \ldots \ldots \ldots \ldots \ldots \ldots$

2.3. Assembled test cell with sample lines attached and test coupons displayed $\ldots \ldots \ldots 6$

2.4. Chromatogram of DMMP and DIMP $\ldots \ldots \ldots \ldots \ldots \ldots \ldots \ldots \ldots \ldots \ldots \ldots$

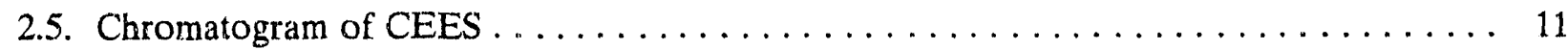




\section{LIST OF TABLES}

Table Page

2.1. Physical Dimensions of Porous Media Coupons Used in Testing $\ldots \ldots \ldots \ldots \ldots \ldots$

2.2. Recoveries of DIMP following aqueous grinding and extraction with MTBE $\ldots \ldots \ldots 13$

2.3. Recoveries of DIMP following delays in MTBE extraction $\ldots \ldots \ldots \ldots \ldots \ldots \ldots$ 


\section{SUMMARY}

In the event of an unplanned release of chemical warfare aigent during any phase of the Chemical Stockpile Disposal Program (CSDP), a (small) potential exists for contamination of buildings and materials used in their construction. Guidelines for unrestricted access to potentially agent-contarninated private and public property are presently undefined due to uncertainties regarding the adequacy of decontaminating porous surfaces such as wood, masonry and gypsum wall board. Persistent agents such as VX or mustard are particularly problematic.

The report which follows documents a measurement protocol developed in a scoping investigation characterizing the permeation of chemical warfare agent simulants [diisopropylmethyl phosphonate (DIMP) for warfare agent GB, dimethylmethyl phosphonate (DMMP) for warfare agent VX, and chlorethylethyl sulfide (CEES) for warfare agent sulfur mustard] through several, common porous, construction materials. The "porous media" selected for examination were wood, brick, cinder block, and gypsum wall board. Simulants were tested rather than actual warfare agents because of their low toxicity, commercial availability, and the lack of surety capability at Oak Ridge National Laboratory (ORNL). The present work is considered a protocol for confirmation testing with "live" agents. Experimentally, the work consisted of

- original protocol dcvelopment and analytical calibrations,

- applying protocol methods to characterize our porous media and a glass blank,

- determining simulant permeation rates through each medium at two temperatures,

- measuring the amount of simulant permeating through meda following a simulated decontarnination procedure,

- exarnining methods for determining mass balance of simulants in each medium.

A permeation rate cell was developed to facilitate measurements. Cylindrical coupons of each medium were placed in the test cell, and three sample regions were isolated by Viton seals. The regions were the spiked space, the side breakthrough space, and the lateral space. Each simulant war spiked on one side of the coupon mounted in the test cell, and unpressurized air samples drawn through all three sample spaces were collected in sorbent traps containing Chromosorb 106. The traps were analyzed by thermal desorption gas chromatography, using sulfur-or phosphorus-specific detection. Protocols simulating those procedures used for agent under actual field conditions were developed for decontamination tests on glass and wood.

Given the number of matrices, simulants, possible test conditions, and lack of consistent performance of the test media, it was difficult to provide definitive results for each of the materials under all conditions. Rather, it is necessary to view the work as a scoping study, capable of 
determining the fundamental parameters of investigation, and identifying those areas requiring more detailed examination.

Results indicate that simulant movement through wood is nearly always in the direction of the wood grain. CEES penetrated all test media more quickly (less than one hour) than the DIMP or DMMP (usually several hours). DIMP and DMMP permeated brick in the lateral direction as well. In one experiment conducted with concrete, DIMP and DMMP behaved differently from each other, and penetrated the concrete at lower concentrations than those observed with other media. Gypsum wall board was penetrated by all simulants in both the lateral and breakthrough directions. Considerable variation in individual tests was observed. Decontamination of wood using high test hypochlorite was not completely effective, although it appeared that greater than $95 \%$ of the DIMP was removed. In some cases, increasing the temperature decreased the time to penetration, but the findings were not consistent. 


\title{
PROTOCOL FOR DETERMINATION OF CHEMICAL WARFARE AGENT SIMULANT MOVEMENT THROUGH POROUS MEDIA
}

\author{
R. A. Jenkins \\ M. V. Buchanan \\ R. Merriweather \\ R. H. Ilgner \\ T. M. Gayle \\ J. H. Moneyhun
}

A. P. Watson

\section{INTRODUCTION}

Gui elines for public aciess to potentially agent-contaminated private property are presently undefined due to uncertainties regarding the adequacy of decontaminating porous surfaces (wood, masonry, gypsum wall board, etc.) (Watson and Munro, 1990). Persistent agents such as VX or mustard are particularly problematic. Even after thorough surface decontamination, agent desorption from porous surfaces could continue over a currently unknown period of time. This report describes an initial scoping investigation concerning the permeation of chemical agent simulants through porous common building materials. Experiments were performed with simulants rather than actual warfare agents because of simulants' low toxicity, commercial availability, and the lack of surety capability at ORNL. All studies were conducted with the following agent simulants: dimethylmethyl phosphonate (DMMP; $\mathrm{C}_{3} \mathrm{H}_{9} \mathrm{PO}_{3}$ ) for organophosphate nerve agent VX, diisopropylmethyl phosphonate (DIMP; $\mathrm{C}_{7} \mathrm{H}_{3.7} \mathrm{PO}_{3}$ ) for organophosphate nerve agent $\mathrm{GB}$, and chloroethylethyl sulfide (CEES; $\mathrm{C}_{4} \mathrm{H}_{9} \mathrm{CIS}$ ) for the vesicarii agent formulations containing sulfur mustard ( $\mathrm{H}, \mathrm{HD}$, and $\mathrm{HT})$. Agent VX is O-ethyl-S2-(diisopropylarninoethyl) methyl phosphonothiolate $\left(\mathrm{C}_{11} \mathrm{H}_{26} \mathrm{NO}_{2} \mathrm{PS}\right.$; CAS No. 50782-69-9); agent GB is O-isopropylmethylphosphonofluoridate $\left(\mathrm{C}_{4} \mathrm{H}_{10} \mathrm{FO}_{2} \mathrm{P}\right.$; CAS No. 107-44-8), while the sulfur mustard agents are various formulations of bis (2-chloroethyl) sulfide $\left(\mathrm{C}_{4} \mathrm{H}_{8} \mathrm{Cl}_{2} \mathrm{~S} ; \mathrm{CAS}\right.$ No. 505-60-2). These agents are characterized more fully in Carnes (1989), and Watson et al (1989), among others.

The work is designed to develcp a measurement protocol for later confirmation testing with active warfare agents. The intent of this document is to describe the protocols developed during the study, and the justification for such protocols.

\section{EXPERIMENTAL}

\subsection{EXPERIMENTAL DESIGN}

The multiple objectives of this scoping study were as follows:

- developing an original experimental protocol and the associated anayltical calibrations,

- applying protocol methods to characteriz: selected porous media and a glass blank, 
- determining simulant permeation rates through each medium at two temperatures,

- measuring the amount of simulant permeating through media following a simulated decontamination procedure,

- examining methods for determining mass balance of simulants in each medium.

A number of experimental, instrumental, and mechanical protocols were developed to accomplish these objectives. These are:

- emplacement of high-speed analytical methods for the simulant vapors.

- design, fabrication, and testing of a test cell pernitting evaluation of the permeation rate under a variety of conditions.

- development of a system to accurately measure the very low air flow rates $(<10 \mathrm{~mL} / \mathrm{min})$ through the test cell.

- Testing of various porous media and a glass blank under two different ternperature conditions.

- development of decontamination protocols to simulate those used under field conditions.

- investigation of procedures for determining the amount of agent simulant remaining in the coupons following permeation measurements.

The basic experiment performed in each test was to spike a coupon of construction material with known concentrations of undiluted simulant on the sample face of the coupon, and collect unpressurized air samples of simulant concentrations evaporating from the sample face, as well as from the breakthrough and lateral spaces of the coupon, for time periods ranging from a few minutes to several days. The concentration of simulant used for each spike was derived from data documenting the maximum amount of undiluted nerve agent on skin that elicited no toxic response in human subject tests (6 mg for agent GB; Grob et al. 1953). Air samples were analyzed for the presence of simulants, and the rate of permeation determined.

Determining permeation rates through various construction materials of the three agent simulants DIMP, DMMP, CEES was performed at ambient $\left(72-74^{\circ} \mathrm{F}\right)$ and an elevated temperature $\left(90^{\circ} \mathrm{F}\right)$. Material balance was examined to quantify how much of the simulant permeated through the test coupon, and how much remained within the coupon. Material balance following a simulated decontamination procedure was also examined.

\section{MATERIAL}

Five building materials used in numerous commercial and residential structures were tested in the study. The materials (unpainted wood, brick, gypsum wall board, concrete block, window glass) 
were obtained from local construction supply vendors. External dimensions are presented in Table 2.1. The wood was unpainted fir board, and the gypsum board was paper covered.

Table 2.1. Physical Dimensions of Porous Media Coupons Used in Testing

\begin{tabular}{||l|c|c|}
\hline \multicolumn{1}{|c|}{ MATERIAL } & $\begin{array}{c}\text { THICKNESS } \\
(\mathrm{mm})\end{array}$ & $\begin{array}{c}\text { SURFACE AREA } \\
(\mathrm{mm})^{2}\end{array}$ \\
\hline Wood & 20 & $\begin{array}{c}3318^{\mathrm{a}} \\
(\mathrm{d}=65 \mathrm{~mm})\end{array}$ \\
\hline Brick & 19 & $\begin{array}{c}2376^{\mathrm{a}} \\
(\mathrm{d}=55 \mathrm{~mm})\end{array}$ \\
\hline Gypsum board & 13 & $\begin{array}{c}3318^{\mathrm{a}} \\
(\mathrm{d}=65 \mathrm{~mm})\end{array}$ \\
\hline Concrete block & 25 & $\begin{array}{c}2376^{\mathrm{a}} \\
(\mathrm{d}=55 \mathrm{~mm})\end{array}$ \\
\hline Glass & 19 & $\begin{array}{c}2703^{\mathrm{b}} \\
(\mathrm{l}=53 \mathrm{~mm}) \\
(\mathrm{w}=51 \mathrm{~mm})\end{array}$ \\
\hline
\end{tabular}

a disc.

${ }^{b}$ rectangle.

\section{TEST CELL DESIGN}

Design criteria for the cell included a number of factors. These were:

- the need to effectively seal three regions of the test coupon. These were the volumes adjacent to the spiked (sample) face and the breakthrough face as well as the lateral space (volume adjacent to the "raw" edge of the coupon) (see Fig. 2.1),

- the ability to change sampling tubes rapidly and easily,

- the ease of disassembly, decontamination, and cleaning, and

- the ability to use commonly available fittings and sealing materials

The test cell eventually developed is portrayed diagrammatically in Figure 2.1. Photographs of the cell are presented in Figures 2.2 and 2.3. The coupon of brick, wallboard, etc. is sandwiched between two stainless steel plates, and the test region is sealed with Viton ${ }^{\otimes}$ O-rings. The two steel plates are secured with C-clamps, and an outer flange enclosing the lateral space is clamped into place with an adjusting bolt. This outer flange is sealed with a Teflon gasket. There are two Swagelok ${ }^{\circledast}$ fittings for each sample region (spike, breakthrough, and lateral space). One is used as 
Sample coupon

Purge ports

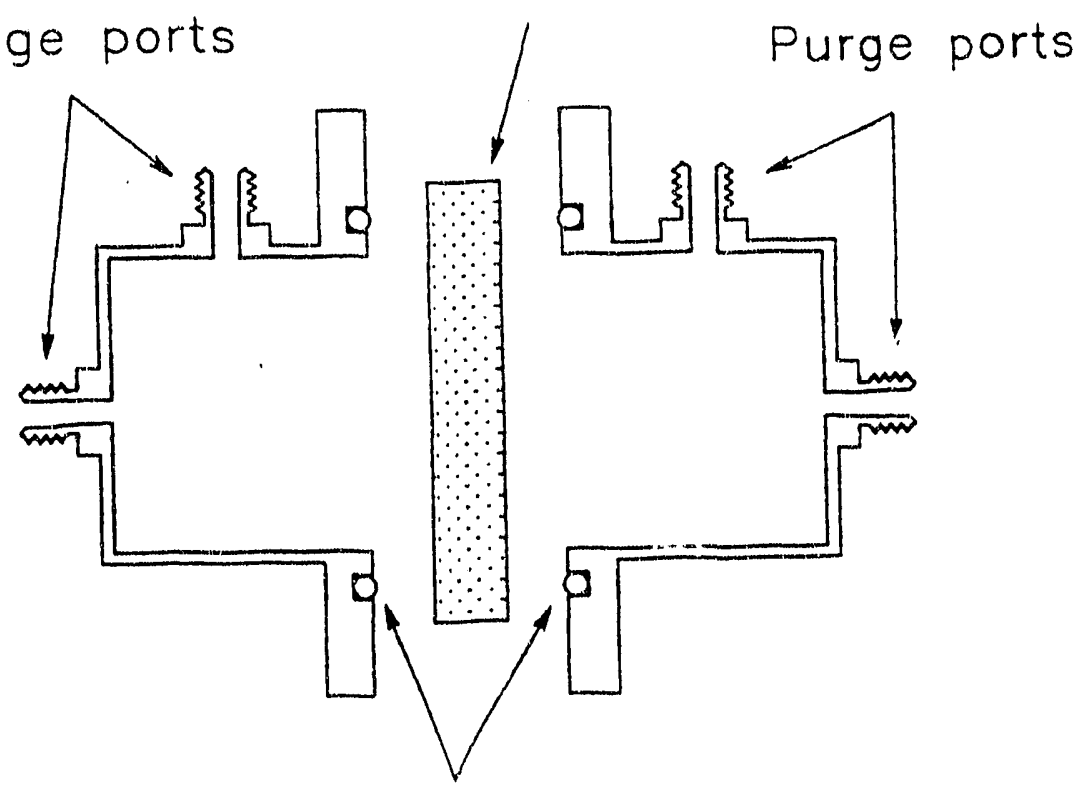

Viton $\mathrm{O}$-ring seal

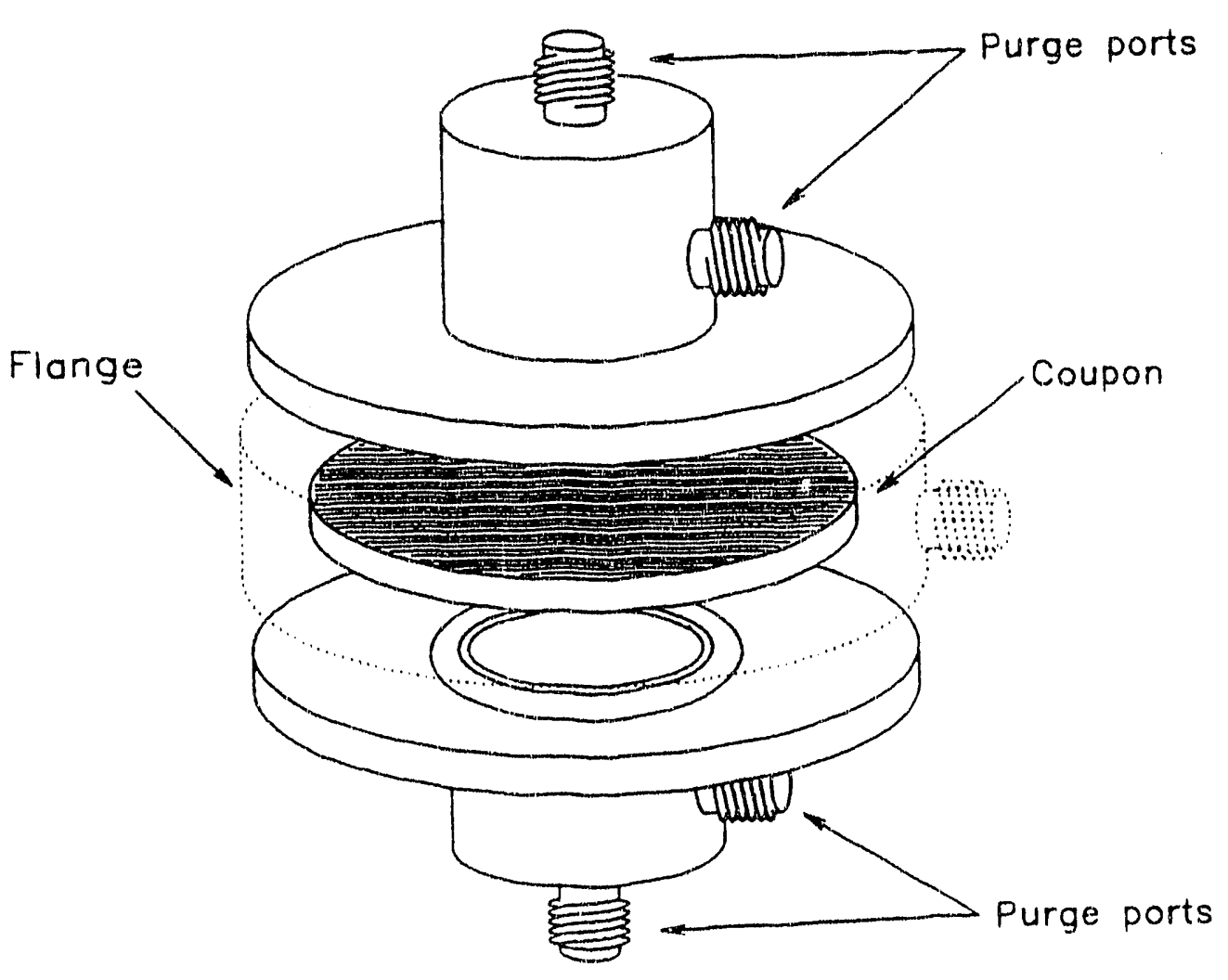

Figure 2.1. Schematic diagram of test cell 


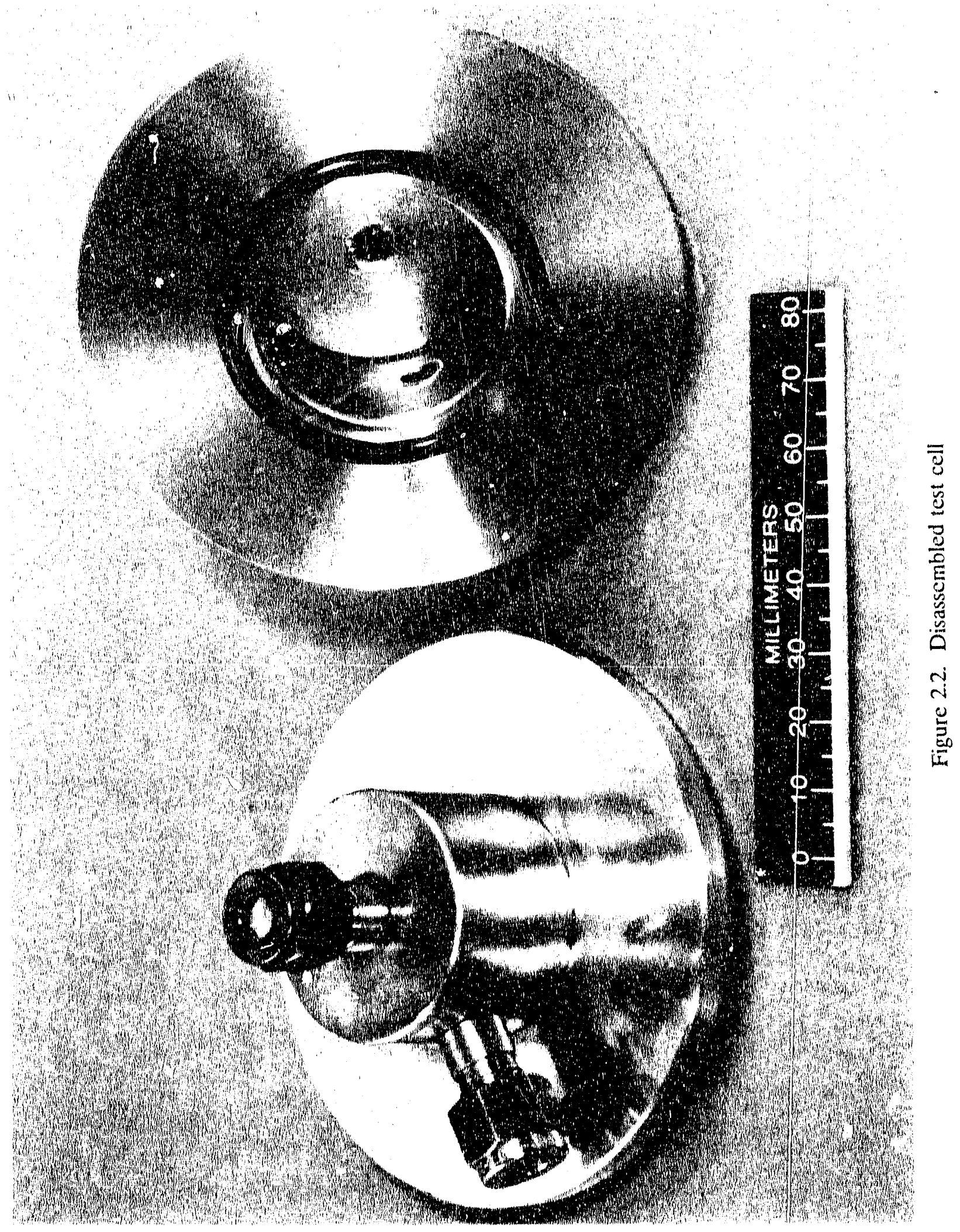




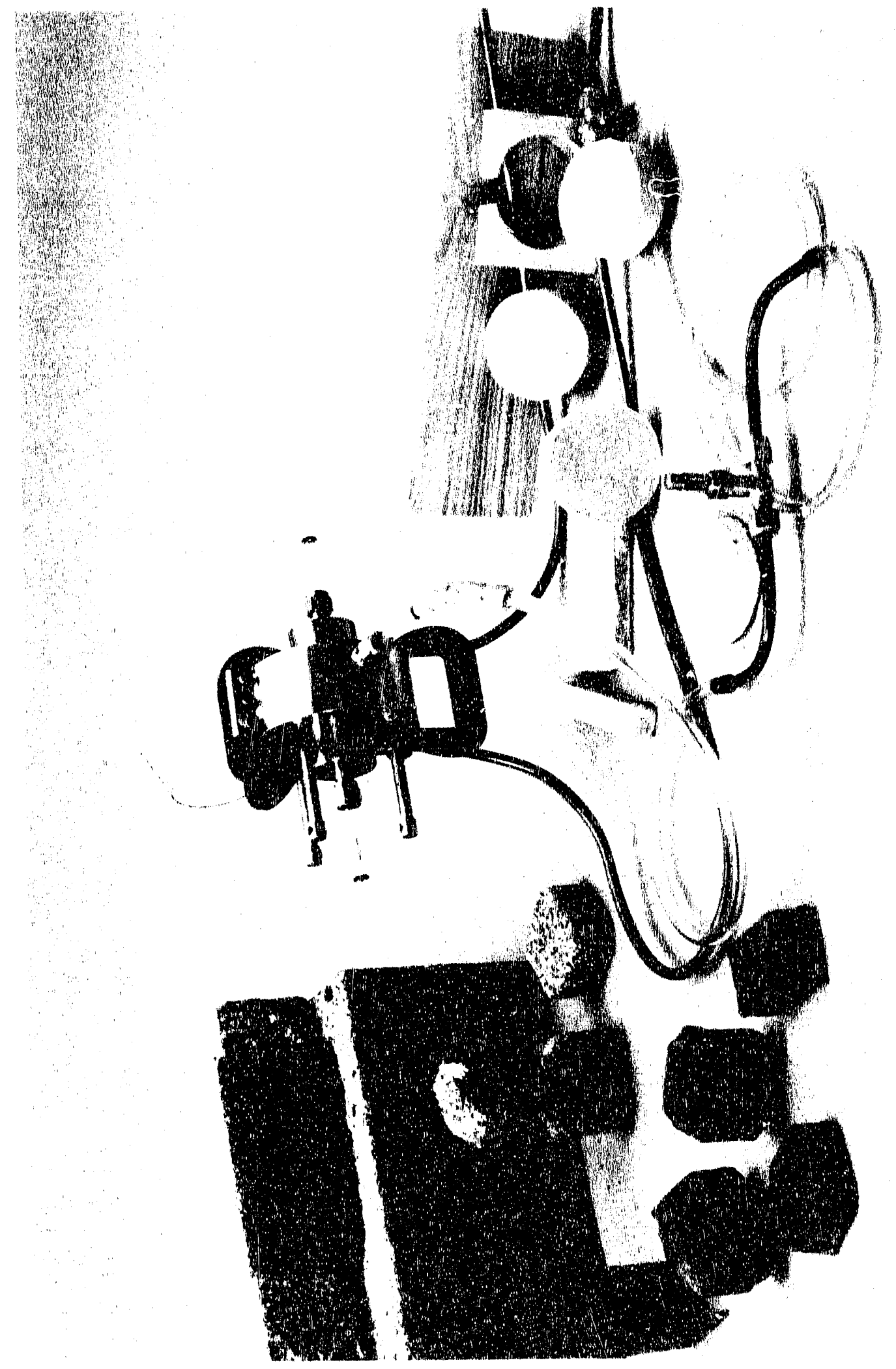

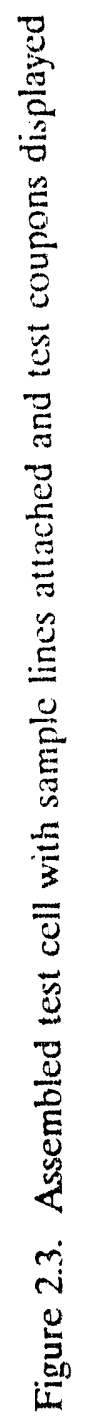


a fitting for the sorbent traps, and the other for an air inlet or outlet. Changing the traps is relatively straightforward. The tubing connecting the flow system is removed, and the fitting in which the trap is held is loosened. The trap is removed, a fresh + ap inserted, the fitting tightened, and the tubing reconnected. The entire process requires approximately $45 \mathrm{sc}:$ A short time is essential for this operation to keep simulant loss from the airspace at a minimum. Following experimental use, the c.ll is disassembled and cleaned by sonicating in soapy water, rinsed, and cleaned with methanol. The cell is then heated at $100^{\circ} \mathrm{C}$. for ca. 2 hours.

For the elevated temperature studies, the cell was maintained at a temperature that would keep the air at the surface of the sample face at a constant $90^{\circ} \mathrm{F}$. This was accomplished by wrapping the cell with electrical heating tape wired to a variable-voltage power supply. A thermocouple was run through the air inlet to the spiked face, and positioned so that temperature measurements could be made in air immediately adjacent to the surface of the soupon.

\subsection{AIR SAMPLING AND FLOW DETERMINATION}

Two different traps were used for the simulant experiments. For DIMP and DMMP,the Depot Area Air Monitoring Sysiem (DAAMS) tubes were employed. These are $6 \mathrm{~mm}$ o.d. $\times 75 \mathrm{~mm}$ long glass tubes filled with the sorbent Chromosorb 106. These were purchased from CMS Research Corp. (Birmingham, Alabama). For the experiments with CEES, tubes of the same size were packed with Tenax, a poly(p-2,6-diphenyl)-phenylene oxide (available from SKC South, Appomattox, VA).

Original consideration was given to using flows through the cell spaces equivalent to a linear velocity of $1 \mathrm{~m} / \mathrm{sec}$. This is a velocity often used to characterize stable atmospheres when nearmaximum inhalations doses are estimated from atmospheric model analysis (Miller and Kornegay, 1989). However, the speed of $1 \mathrm{~m} / \mathrm{sec}$ would have resulted in a flow rate across the sample and breakthrough spaces of $68 \mathrm{~L} / \mathrm{min}$. There were several problems with this approach. Given the relatively small volume of the cell cavities, this would have resulted in more than 10 air changes per second. At this rate, it was likely that the undiluted agent simulant would evaporate from the surface prior to any penetration of the porous media. At such a llow rate, there was likely to be significant pressure drop across the sampling tube. The resulting pressurization of the cell may have led to unrepresentative movement of the simulant through the coupon. Also, breakthrough of the simulants trapped on the sorbents would be likely, especially at long sampling times. For these reasons, it was decided to use the lowest practical air flows through the sample cell. Thus, evaporation of the simulant at the point of the spike would be minimized. In addition, low sampling flow rates would permit much longer sampling times without exceeding the capacity of the sorbent traps. 
In some of the earlier experiments, air flow through the spiked and breakthrough spaces (and through the sorbent traps) was accomplished by means of a pressurized cylinder of breathing air at a nominal rate of $2.5 \mathrm{~mL} / \mathrm{min}$. Air was pulled through the lateral space onto the traps using "house" vacuum, at a rate of ca. $5 \mathrm{~mL} / \mathrm{min}$. Flow rate was determined at the beginning and end of each sampling period using a small bubble meter. Some variation in the flow rates over time were noted. This caused some concern, since even a modest change in the absolute flow rate at such low flows can result in a substantial relative change. (For example, $0.5 \mathrm{~mL} / \mathrm{min}$ is $20 \%$ of $2.5 \mathrm{~mL} / \mathrm{min}$.) Precise air flow measurements together with accurate total flow volumes are obviously vital to the realistic determination of simulant transport values. The very small air flow rates involved $(2-6 \mathrm{~mL} / \mathrm{mm})$ in the spike, breakthrough, and lateral spaces of the test cell made accurate flow measurement by conventional manual techniques difficult and inaccurate. Later use of commurcially available mass flow meters interfaced to ORNL-developed digital electronic integrators similar to those reported previously (Jenkins and Gayle 1980) proved to be a superior method and provided accumulated volumetric values accurate to better than $\pm 1.0 \%$ in all cases.

The ultimate flow rate arrangement operated from a stabilized vacuum source and employed three similar flow circuits for the three cell chambers. Each circuit pulled an air sample through the chamber sampling tube, into the mass flowmeter, through a precision metering valve and on to the stabilized vacuum source. The three mass flowmeters were Sierra Model 821-2-10CC units (Sierra Instruments, Inc., Monterey, CA 93940). Stated accuracy of these units was $\pm 2 \%$. However, they were calibrated to better than $\pm 0.25 \%$ accuracy using a Buck model M-5 Volumetric Calibrator (A.P Buck, Inc.,Orlando, FL 32006). The vacuum source used in all tests was laboratory "house vacuum" which normally varies from 20 to 28 inches of mercury. This was stabilized at 15 inches of mercury to provide a constant source for consistent manual flow rate control. To stabilize the vacuum for all three circuits, a single Conoflow Model H-20VT-15 Vacuum Regulator (ITT/Conoflow Corp., St. George, SC 29477) was employed. Setting the desired flow rate was accomplished using a Nupro Model B-SS4-VH Precision Metering Valve (Nup: o Division, the Swagelok Companies, Willoughby, $\mathrm{OH} 44049$ ) in each circuit between the mass flowmeter and the stabilized vacuum source.

The Sierra Mass Flowmeters provide a local digital readout of flow rate as well as a linear voltage output directly proportional to flow rate. Each of these three voltage signais was channeled to a model Q-5873-3 digital electronic integrator similar to that reported in Jenkins and Gayle (1980). These units accept a voltage input and use a precision voltage-to-frequency circuit to drive a high speed seven digit electronic counter. The voltage signals were scaled so as to make the counter digits read directly in milliliters, the least digit being $.01 \mathrm{~mL}$. The overall combined accuracy of the 
components involved in the system provided a totalized (volume) accuracy of better than $\pm 1 \%$. Periodic (every 21 days) recalibration has verified this accuracy.

\section{ANALYTTCAL PROCEDURES}

\subsubsection{DIMP (GB simulant) and DMMP (VX simulant)}

These GB and VX simulants were analyzed sim!'taneously using on-column thermal desorption gas chromatography with phosphorus-specific flame photometric detection. The DAAMS tube is placed in a cold thermal desorber unit, and heated rapidly for 10 seconds to $220^{\circ} \mathrm{C}$. Helium carrier gas flowing at $28 \mathrm{~mL} / \mathrm{min}$ sweeps the effluent of the trap onto the analytical column, which is a $30 \mathrm{~m}$ long $\times 0.53 \mathrm{~mm}$ i.d. DB-210 bonded phase fused silica capillary column. The flame photometric detector is set in the phosphorus-specific mode at $525 \mathrm{~nm}$. Hydrogen and air flow rates were $120 \mathrm{~mL} / \mathrm{min}$ and $175 \mathrm{~mL} / \mathrm{min}$, respectively. Based on a preliminary evaluation of the separation performance of the capillary column, the following temperature program was utilized to achieve adequate resolution of DIMP and DMMP: an initial hold at $70^{\circ} \mathrm{C}$ for 30 seconds, followed by an increase to $150^{\circ} \mathrm{C}$ at the rate of $20^{\circ} \mathrm{C}$ per minute. The final temperature was held for 5.0 minutes. Detector temperature was $200^{\circ} \mathrm{C}$. The chromatograph used was a Tracor Model 540. Elition time was $1.7 \mathrm{~min}$ for DMMP, and $1.24 \mathrm{~min}$ for DIMP. A sample chromatogram is presented in Figure 2.4.

\subsection{CEES (Sulfur mustard simulant)}

The Tenax trap was placed in a cold thermal desorber unit, and heated rapidly for 15 seconds to $250^{\circ} \mathrm{C}$. Helium carrier gas flowing at $7 \mathrm{~mL} / \mathrm{min}$ swept the effluent of the trap onto the analytical column, which is a $30 \mathrm{~m}$ long $\mathrm{x} 0.53 \mathrm{~mm}$ i.d., $1.0 \mu \mathrm{m}$ film thickness DB-5 bonded phase fused silica capillary column. The flame photometric detector was set in the sulfur-specific mode at $393 \mathrm{~nm}$. The hydrogen and air flow rates were $100 \mathrm{~mL} / \mathrm{min}$ and $150 \mathrm{~mL} / \mathrm{min}$. Based on preliminary examination of the DB-5 column performance, the following temperature program was utilized so as to achieve adequate separation between the CEES and other contaminants present: an initial hold at $70^{\circ} \mathrm{C}$ for 4 minutes, followed by an increase to $150^{\circ} \mathrm{C}$ at the rate of $8^{\circ} \mathrm{C}$ per minute. The final temperature was held for 2.0 minutes. Detector temperature was $200^{\circ} \mathrm{C}$. The chromatograph used was a Tracor Model 540. Elution time for the CEES was 7.9 minutes. A sample chromatogram is presented in Figure 2.5.

\subsection{PROCEDURES FOR DECONTAMINATION SIMULATION}

The effectiveness of decontamination was studied for glass as the reference material, and wood as the test medium. Technical Escort Operations of the U.S. Department of the Army are 


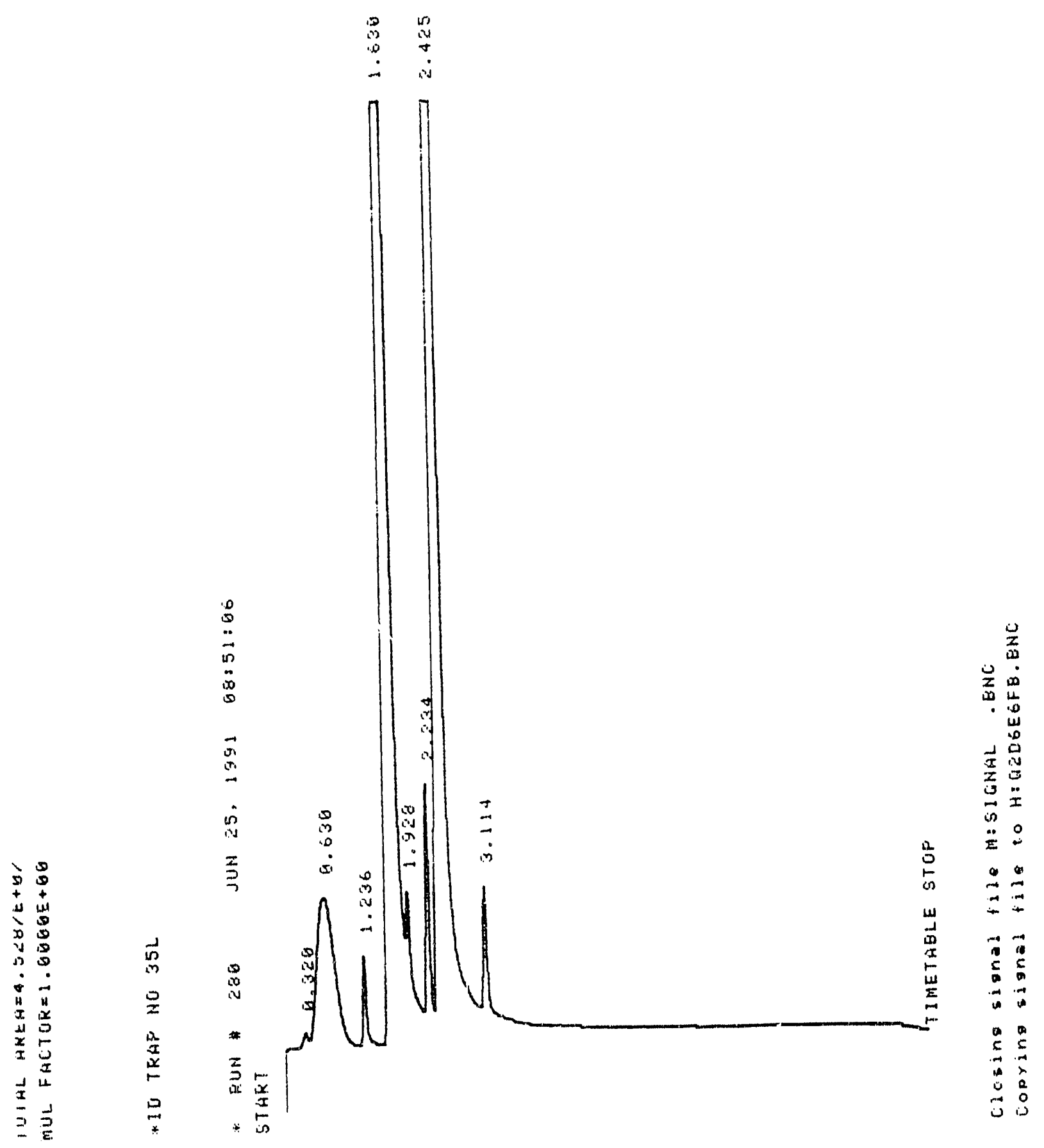

Figure 2.4. Chromatogram of DMMP and DIMP. Elution times are 1.63 minutes and 2.435 minutes, respectively. 


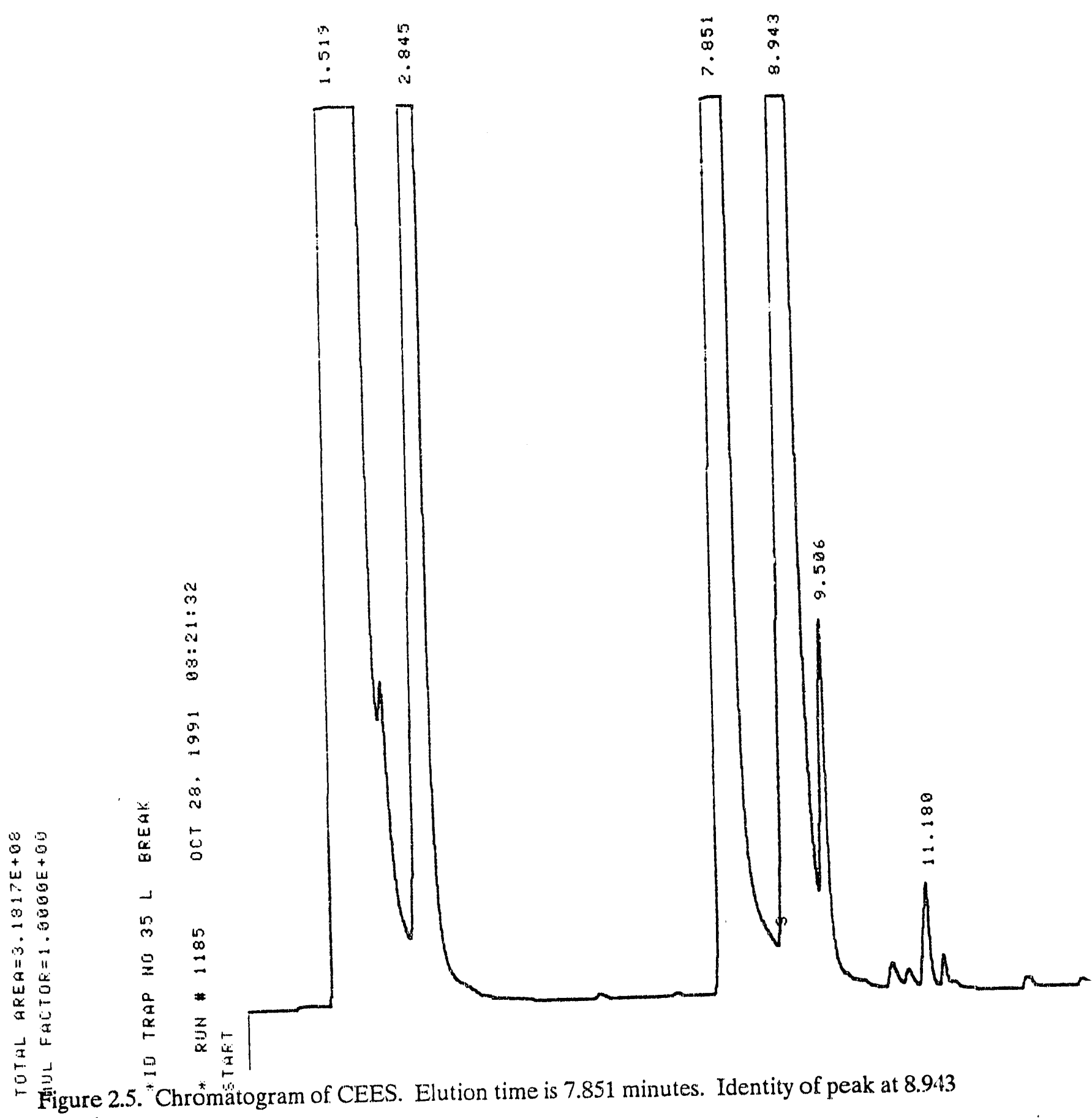
minutes is unknown. 
governed by detailed guidance for the decontamination of materials (U.S. Dept. of the Army, 1981). These include both the exact composition of the decontamination mixture, the arnount applied per unit area, and the procedure to be used. The Army specifies decontamination of glass with soapy water, and of wond, with a slurry of high test hypochlorite (HTH). High test hypochlorite is commonly used as a chlorine source in swimming pools. Procedures specified in the Army guidance were scaled down, and applied to the test and reference materials.

Both the wood and glass coupons were spiked with $6 \mathrm{mg}$ each of DIMP and DMMP outside the test cell. The spike concentration corresponds to the maximum amount of nerve agent on skin that generates no toxic response in human subject tests (Grob et al. 1953). Each spiked coupon was allowed to stand in a fume hood for 4 hours, to approximate an estimated time for a decontamination unit to respond in an area outside the installation boundary. The glass surface was then flushed with ca. $30 \mathrm{~mL}$ of hot soapy water and dried with a paper towel. The wood surface was decontaminated by application of $1.5 \mathrm{~g}$ of an HTH slurry (ca. $100 \mathrm{~g}$ of high test hypochlorite and $100 \mathrm{~mL}$ of water) to the $32.2 \mathrm{~cm}^{2}$ surface with a plastic spoon. After allowing the slurry to stand on the spiked wood for $12-24$ hours, the slurry was flushed away with ca. $100 \mathrm{~mL}$ of water. This process was repeated a total of three times. The coupons were then installed in individual test cells, and air samples taken over the course of a few days.

\subsection{RECOVERY OF AGENT SIMULANTS FROM TEST COUPONS}

A number of approaches were examined for the recovery of simulants spiked onto test materials. Test protocols were evaluated for DIMP spiked on concrete as a worst case. Previous testing in our laboratory had suggested that DIMP would be absorbed into the concrete matrix and little would migrate through the coupon. It was unknown, but suspected, that the DIMP was undergoing chemical reaction with constituents of the concrete and producing a non-permeating species.

Initial tests with ground, spiked concrete in air met with limited success. Concrete was broken into several small pieces, and individual pieces placed in glass vials. Exactly $6 \mathrm{mg}$ of DIMP in methanol solution $(0.9 \mathrm{mg} / \mathrm{Ml})$ was spiked directly onto the face of a concrete chip. The vial was sealed for two hours to permit penetration of the spike into the concrete.

Initial grinding tests were performed under water. To accomplish this, the spiked chip was further b.oken with a pointed chisel and hammer. All pieces were then placed in a mortar, covered with distilled water, and ground to a fine powder with a pestle. The water and ground concrete were extracted with $250 \mathrm{~mL}$ of methyl tertiary butyl ether (MTBE). The MTBE was separated from the aqueous phase using a separatory funnel. The aqueous phase was washed with excess MTBE in two, 
$50 \mathrm{~mL}$ portions; the washes were added to the first $250 \mathrm{~mL}$ of MTBE extract. Volume of the resulting $350 \mathrm{~mL}$ solution was reduced to $10 \mathrm{~mL}$ under dry nitrogen. Results of this experiment are provided in Table 2.2 .

Table 22. Recoveries of DIMP following aqueous grinding and extraction with MTBE

\begin{tabular}{|c|c|}
\hline Experiment No. & DIMP Recovery, \% \\
\hline \hline 1 & 75 \\
\hline 2 & 52 \\
\hline
\end{tabular}

To determine if losses of DIMP were occurring due to evaporation, or reaction with the concrete, a series of experiments were performed in which some delay occurred following the sample spike, prior to addition of MTBE extractant. Following the addition of MTBE, the samples were allowed to stand overnight. No volume reduction was performed, and the extract analyzed by GC, as described below. Results of these experiments ate reported in Table 2.3.

Table 2.3. Recoveries of DIMP following delays in MTBE extraction

\begin{tabular}{|c|c|c|}
\hline Sample No. & $\begin{array}{c}\text { Time delay following } \\
\text { extraction, hrs. }\end{array}$ & $\begin{array}{c}\text { DIMP Recovery } \\
\%\end{array}$ \\
\hline \hline $1 \mathrm{~A}$ & 17 & 48 \\
\hline $1 \mathrm{~B}$ & 17 & 51 \\
\hline $2 \mathrm{~A}$ & 0.5 & 70 \\
\hline $2 \mathrm{~B}$ & 0.5 & 67 \\
\hline $3 \mathrm{~A}$ & 0 & 53 \\
\hline $3 \mathrm{~B}$ & 0 & 51 \\
\hline
\end{tabular}

The results of these two experiments suggested that extraction using MTBE in this manner could probably consistently achieve no greater than $50 \%$ recovery. As a result of the poor recoveries obtained, we developed a novel method employing Suxhiet extraction with an organic solvent. 
The entire DIMP-spiked coupon of concrete was placed in the extraction thimble of a Soxhlet extraction system. Methyl t-butyl ether (MTBE) was the extraction solvent. The unit was heated and the extraction conducted for approximately 4 hours. The extract was concentrated under dry nitrogen, and an aliquot analyzed using the method described below. Recovery of DIMP by this procedure was $94 \%$. Time and resource limitations precluded further testing.

Note that this procedure is quite different from the procedure previously described in Section 2.5 for analyses of DAAMS tubes. However, we consider that the DAAMS tube procedure could also be used by spiking an aliquot of the MTBE extract on a DAAMS tube, hlowing off the solvent with dry helium, and analyzing the tube appropriately.

The DIMP was analyzed using a GC with phosphorus-specific thermionic detection. A $2 \mu \mathrm{L}$ aliquot of extract was injected into the $\mathrm{GC}$, with the injector held at $200^{\circ} \mathrm{C}$. Helium carrier gas flow was $3.3 \mathrm{~mL} / \mathrm{min}$ through the analytical column, which is a $30 \mathrm{~m}$ long $\mathrm{x} 0.53 \mathrm{~mm}$ i.d. DB-23 bonded phase fused silica capillary column, with a $0.5 \mu \mathrm{m}$ film thickness. Make-up gas flow was $30 \mathrm{~mL} / \mathrm{min}$. The thermionic detector was set in the phosphorus-specific mode. Hydrogen and air flow rates were 5.6 and $100 \mathrm{~mL} / \mathrm{min}$, respectively. The temperature program was an initial hold at $120^{\circ} \mathrm{C}$ for 120 seconds, followed by an increase to $200^{\circ} \mathrm{C}$ at the rate of $10^{\circ} \mathrm{C}$ per minute. Deiector temperature was $250^{\circ} \mathrm{C}$. The chromatograph used was a Varian Model 3700. Elution tirne for the DIMP was 1.56 minutes.

An accurate determination of the material balance with the described protocol would be difficult. A number of technical hurdles must first be addressed. Ideally, to determine the material balance, one should merely add the amount of simulant collected on all of the DAAMS tubes from all of the air spaces (sample, breakthrough, and lateral) over the course of the experiment, and then perform an extraction of the "used" coupon. However, as was noted above, the quantities evaporating from the spiked face of the coupon are so large as to be beyond the quantifiable range of the analytical method. And, despite the apparent high concentrations of simulants present in the lateral or breakthrough spaces observed (as much as several hundred thousand $\mu \mathrm{g} / \mathrm{m}^{3}$ ), the absolute quantities of simulants collected represent a very small fraction of the total amount of material spiked. For example, total quantities of simulants collected typically ranged from $1-500 \mu \mathrm{g}$, which represents $0.02-8 \%$ of the total spike. And while Soxhlet extraction of the coupons would appear to be capable of removing most (95\% of DIMP observed) of the remaining simulant in the coupon, this approach has only been tested once, and at a relatively short elapsed time between spiking and extraction. It is unknown whether this approach would be as effective at one week past the spike time. 
The stability of the simulant, or lack thereof, may also confound determination of an accurate material balance. There is very clear evidence that the CEES decomposes significantly during the experiment, because the decomposition product is chromatographable under the conditions of the analysis. In the case of CEES, it would seem relatively straightforward to identify the decomposition product and quantify it. However, there may be other simulant decomposition products which are not easily chromatographed. An accurate determination of material balance would require a more extensive analysis of the coupons to confirm, identify, or refute, the presence of simulant decomposition products. However, even optimistic assessments suggest that more extensive appraisal will be capable of accounting for no more than $85-90 \%$ of the total spike mass.

\section{CONCLUSIONS}

A protocol and analytical system for determining permeation times of chemical agent simulants through porous construction materials has been developed. The approach involves isolation of three spaces around the coupon; namely, the lateral, breakthrough, and (sample) spike space. The sample face is spiked with a known quantity of nerve or vesicant warfare agent simulant, and the simulant passing through the coupon (or evaporating from the spiked face) is collected in solid sorbent tubes. Sorbent tubes are then chromatographically analyzed. Permeation is defined as the point at which a large change in the air space concentration of simulant occurs.

Simulant movement through wood is nearly always in the direction of the wood grain. CEES penetrated all test media more quickly (less than one hour) than the DIMP or DMMP (usually several hours). DIMP and DMMP permeated brick in the lateral direction as well. Gypsum wall board was penetrated by all simulants in both the lateral and breakthrough directions. Considerable variation in individual tests was observed. Decontamination of wood using high test hypochlorite was not completely effective, although it appeared that greater than $95 \%$ of the DIMP was removed. In some cases, increasing the temperature decreased the time to penetration, but these findings were not consistent. Several procedures for the extraction of simulants from the test cc.spons were also investigated in an effort to determine material balance. Soxhlet extraction permitted $94 \%$ recovery of one simulant on one medium. This approach needs further characterization.

\section{RECOMMENDATIONS FOR FURTHER WORK}

A number of problem areas were identified during protocol development, which suggest that further work may be necessary before definitive work with agents can be performed. These include: 
1. During the initial phase of our experiments, much simulant evaporated from the spiked face of the coupon. Even with sampling times of a few minutes' duration, so much material was collected on the DAAMS tubes that the analytical system was overwhelmed and the detector saturated. The ability to reduce the amount of material collected for analysis should be investigated. Several approaches are possible. These include sample splitting, collection of an air sample in a passivated stainless steel canister, followed by direct air injection into a $\mathrm{GC}$, or a process monitoring approach. The latter refers to establishing an automated gas s.m. ing loop affixed to a dedicated GC, with simulant concentrations determined every few minutes.

2. The difficulty of obtaining a tight seal around a large-pore, rough-surfaced material such as brick or concrete is significant. Consideration was given to placing epoxy on part of the face of these materials to provide a surface against which the Viton O-ring could seal. However, the presence of a foreign material containing solvent would have likely altered simulant permeation behavior. Such an approach was rejected. Nevertheless, a technique for improving the seal against the concrete or brick face should be investigated.

3. The chromatographic behavior of CEES requ es further investigation. This compound, after passing through wood or gypsum wall board, is collected as two individual components in the GC spectrum (See Figure 2.5). Judging from its longer elution time, the bieakdown product appears to be somewhat less volatile than the CEES. Other studies performed in our laboratory have suggested the facile hydrolysis of CEES. Thus, the second peak may in fact be the primary hydrolysis product. However, this needs to be confirmed with more detailed studies.

4. Because of the rapid evaporation and/or hydrolysis of the simulants from coupons, and the inconsistent behavior of the simulants on the coupons themselves, the determination of a materia! balance is difficult. While rough estimates of mass balance can be made using the protocols developed here, accurate determination will :equire more specialized methods. 


\section{REFERENCES}

Grob, D., B. Zeigler, G. Saltzer, and G. I. Johnston (1953), "Further observation of the effects in man of methyl isopropyl fluorophosphonite (GB): Effects of percutaneous absorption through intact and abraded skin." MLCR 14. DA-18-108-CML-3014. Johns Hopkins University and Hospital.

Jenkins, R. A and T. M. Gayle (1980), "An instrumental inhaled smoke dosimeter for the quantitative characterization of aerosol exposures," pp. 68-86 in Pulmonary Toxicology of Respirable Particles. Praceedings of the 19th Annual Hanford Life Sciences Symposium at RIchalnd, Washington, Oct. 22-23, 1979. DOE-CONF-791002.

Miller, R. L. and F. C. Kornegay (1989), "Downwind doses from potential releases associated with the chemical stockpile disposal program." The Environmental Professional 11:315-323.

U. S. Department of the Army (1981), Technical Escort Operations, Report FM 3-20, Headquarters, U.S. Department of the Army, Washington, D. C.

Watson, A. P. and N. B. Munro (1990), Reentry Planning: The Technical Basis for Offsite Recovery Following Warfare Agent Contamination ORNL-6628, Oak Ridge National Laboratory, Oak Ridge, TN 37831-6101. 


\section{INTERNAL DISTRIBUTION}

1. M. V. Buchanan

2. T. M. Gayle

3. W. Griest

4. R. H. Ilgner

5. R. A Jenkins

6. R. Merriweather

7. J. H. Moneyhun

8. J. H. Sorensen

9-29. A. P. Watson

30-31. Central Research Library

32. Document Reference Section

33. Laboratory Records

33. Laboratory Records, RC

34. ORNL Patent Section

\section{EXTERNAL DISTRIBUTION}

35. Linda W. Anderson, Chief, Special Programs Group, CEHIC/CDC, 1600 Clifton Road, Atlanta, GA 30333

36. Kyle Blackman, Chief, Chemical Stockpile Preparedness Branch, Office of Technological Hazards, FEMA, 500 C. Street, SW, Washington, DC 20472

37. Thomas L. Hess, Regulatory Agency Liaison, Office of the Deputy for Chemical Demilitarization, OASA (I, L, and E), The Pentagon, Room 1A875, Washington, DC 203100110

38. Sanford S. Leffingwell, CEHIC/CDC, 1600 Clifton Road, Atlanta, GA 30333

39. Office of Assistant Manager for Energy Research and Development, Department of Energy, Oak Ridge Operations, Oak Ridge, TN 37831

40-49. Office of Scientific and 'Technical Information, Post Office Box 62, Oak Ridge, TN 37831

50. Elizabeth A. Peterson, c/o Commander, HQ AMCCOM, Attention: AMS MC-SE/B. Peterson, Rock Island, IL' 61299-6000

51. J. Richard Ward, U.S. Army Chemical Research Development and Engineering Command, Attention: SMCCR-RSC/J. Richard Ward, Aberdeen Proving Ground, MD 21010-5423 


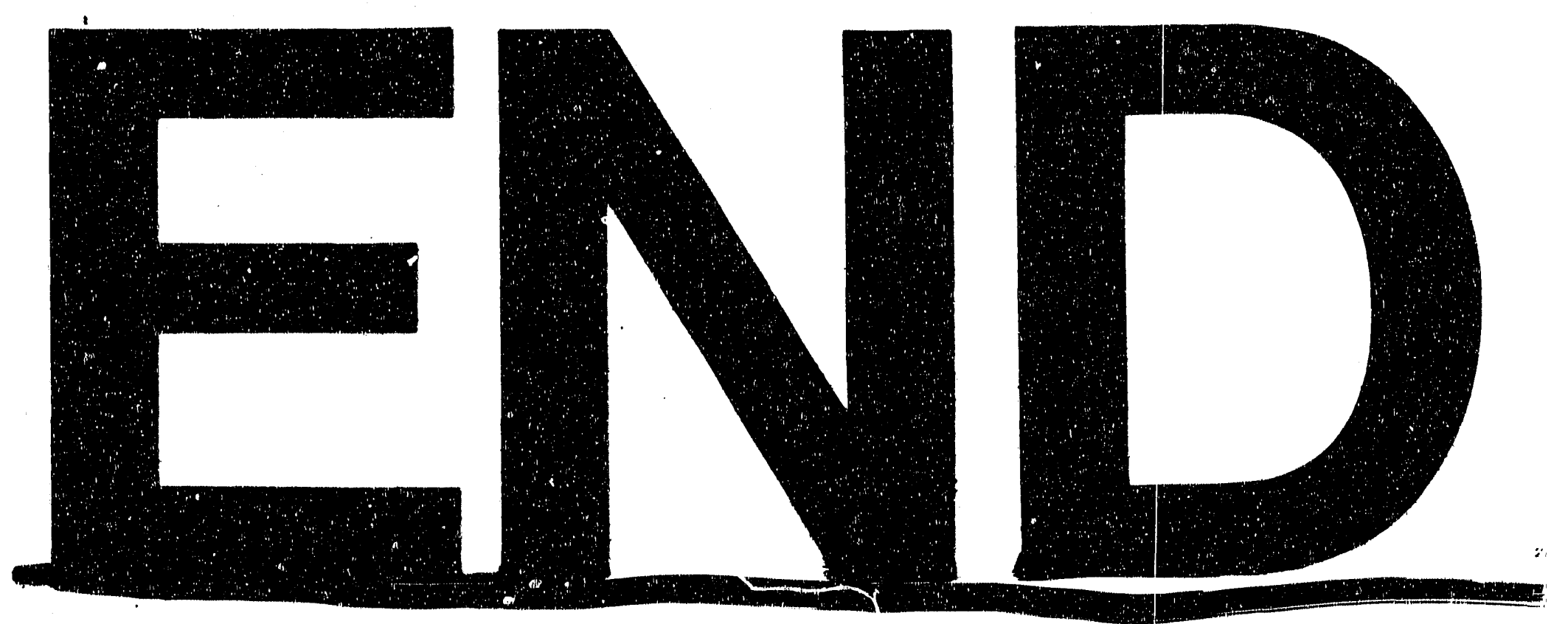

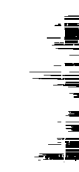
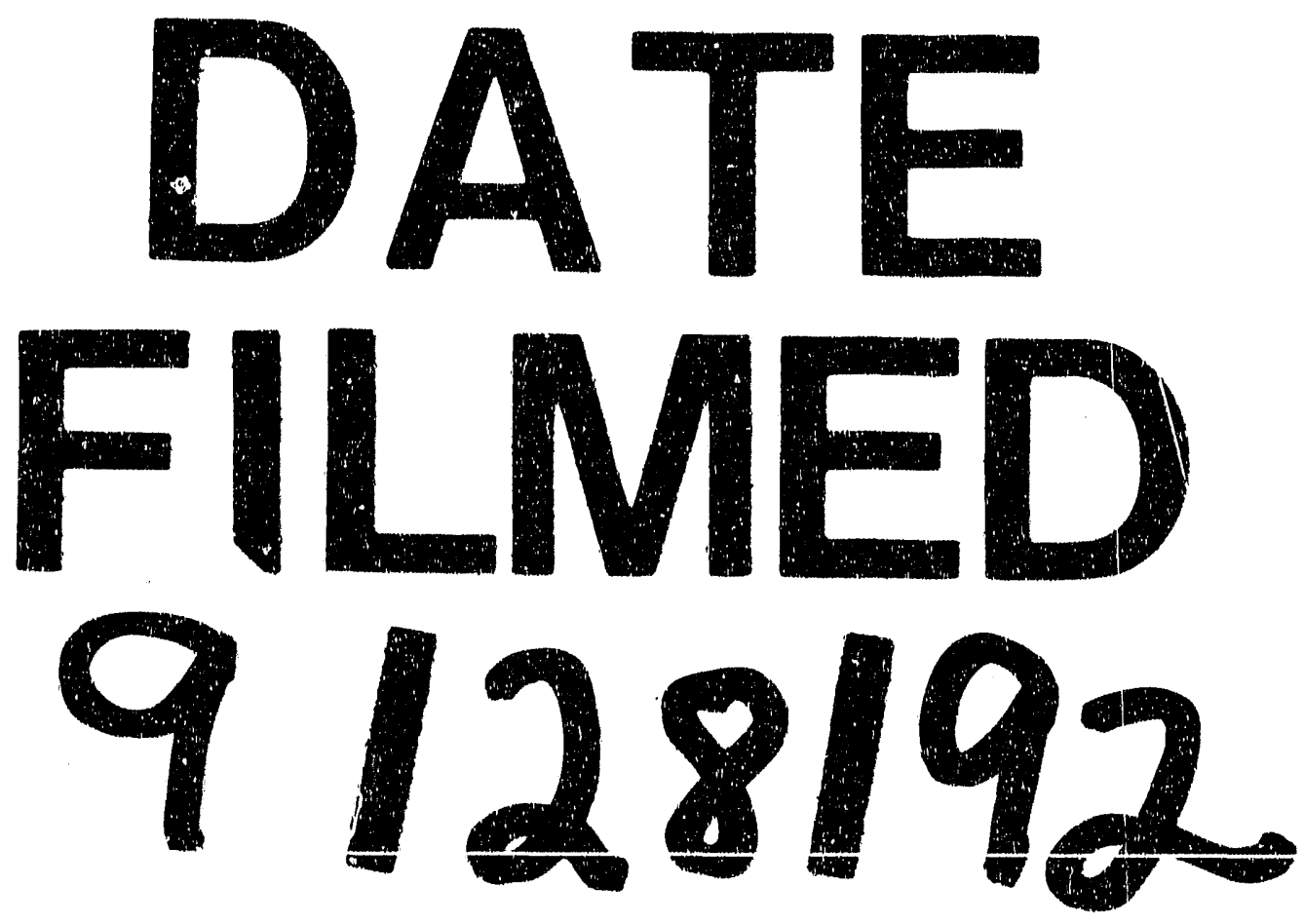


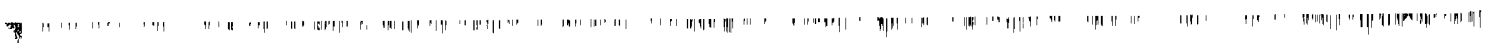

